\title{
CONSTITUTIVE MODELLING AND NUMERICAL IMPLEMENTATION OF SMA MATERIAL WITH INTERNAL LOOPS
}

\section{A. ZBICIAK ${ }^{1}$, K. WASILEWSKI ${ }^{2}$}

\begin{abstract}
The article presents a constitutive model for Shape Memory Alloys (SMA) along with result of dynamic simulations of SMA model. The applications of devices incorporating SMA in civil engineering focus mostly on mitigation of the seismic hazard effects in new-build and historical buildings or improvement of fatigue resilience. The unique properties of SMA, such as shape memory effect and superelasticity give promising results for such applications. The presented model includes additional phenomenon of SMA - internal loops. The paper shows the method of formulation of physical relations of SMA based on special rheological structure, which includes modified Kepes's model. This rheological element, introduced as dual-phase plasticity body, is given in the context of martensite phase transformation. One of the advantages of such an approach is a possibility of formulation of constitutive relationships as a set of explicit differential equations. The application of the model is demonstrated on example of dynamic simulations of three dimensional finite element subjected to dynamic excitation.
\end{abstract}

Keywords: Shape Memory Alloys; Rheological model; Dynamic simulation.

\footnotetext{
${ }^{1}$ PhD., DSc., Warsaw University of Technology, Faculty of Civil Engineering, ul. Lecha Kaczyńskiego 16, 00-637 Warsaw, Poland, e-mail: a.zbiciak@il.pw.edu.pl

${ }^{2}$ MSc., Warsaw University of Technology, Faculty of Civil Engineering, ul. Lecha Kaczyńskiego 16, 00-637 Warsaw, Poland, e-mail: k.wasilewski@il.pw.edu.pl
} 


\section{INTRODUCTION}

Shape Memory Alloys (SMA) belong to the group of materials known as smart materials, which basic characteristic is a possibility of controlled change of properties by application of proper stimulus. In the recent decades the significant growth of the interest in smart materials could be observed. In accordance to Mohd Jani et al. [1] the forecasted compound annual growth rate of the global market of smart materials between 2011 and 2016 reached 12.8\%. One of the main barrier for common application of SMA in the field of structural engineering is its price. In comparison with the other fields, like biomedical or robotics, the application of SMA for the structural purposes requires relatively more material, what explains the significance of economical matter. The growing interest is also connected with the significant reduction of price - form the level of US $\$ 1100$ per kilogram in 1999, US\$111 per kilogram in 2004, down to US\$20-30/kg for mass orders in 2014 [2].

The application of SMA in the field of civil engineering is a result of striving for better natural disaster resilience and demand for high performance of modern structures, as well as safety and adjustment to actual requirements for adaptations of historical buildings [3]. Those can be achieved due to unique characteristics of SMA such as shape memory effects and superelasticity. One-way shape memory effect is a possibility of recovery from the deformed shape once the external force is removed and material is heated. Two-way shape memory effect, in addition to one-way shape memory effect, is a possibility of remembering shape in both high and low temperature. Superelasticity is an ability to return from a relatively high strains to original shape upon a load removal [1]. From the point of view of application of SMA in a field of structural engineering, superelasticity phenomenon is particularly interesting and it is one of the main issues of the material models, used for numerical analysis of structures with SMA applied.

The article presents some of the possible applications of devices that incorporate SMA in the field of civil engineering. The further presented constitutive model of SMA, that includes phenomenon of internal loops was introduced by Wasilewski and Zbiciak [4]. The implementation of the presented model is shown on the basic examples of a three dimensional finite element subjected to dynamic excitation. 


\section{SMA IN STRUCTURAL ENGINEERING}

The application of SMA in structural engineering primarily makes use of two key features of the SMA - superelasticity and energy dissipation through hysteretic behaviour. Those factors could be successfully used for mitigation of consequences of natural hazardous events, such as earthquakes. The selected examples of possible application of SMA for structural purposes are presented below. Widely used engineering solution for a prevention of structural and nonstructural damage as a results of earthquakes are braced frames. One of the conventional solutions is application of steel elements in diagonal orientation that embrace the structure of a frame against horizontal actions. Along superelasticity, the phenomenon of energy dissipation through hysteretic behaviour makes application of SMA based devices successful in such structures. The different configuration of SMA braces were designed and analysed in recent years [5-7]. The basic examples of braced frame structures are given in Fig. 1.
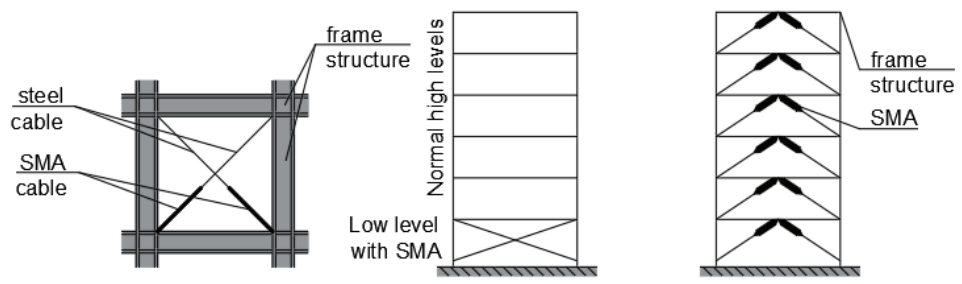

Fig. 1 Schematic representation of possible applications of SMA for frame bracing [5-7].

Researches [2,6,7] show that application of SMA in structural bracing reduced structural damage during the earthquakes. It would effect in $42 \%$ business downtime reduction necessary for full recovery of a building in comparison with conventional steel braces, moving most of the repairs to nonstructural elements of the building [2].

Another solution for mitigation of seismic actions effects that could be improved with SMA are base isolation systems. The main concept of a base isolation devices is an isolation between the base of a structure and the ground that allows the structure to slide in the certain range [5]. The several researches (e.g. [8-10]) present many types of possible applications of SMA in base isolation devices, usually together with rubber bearing. An examples is given in Fig. 2. 

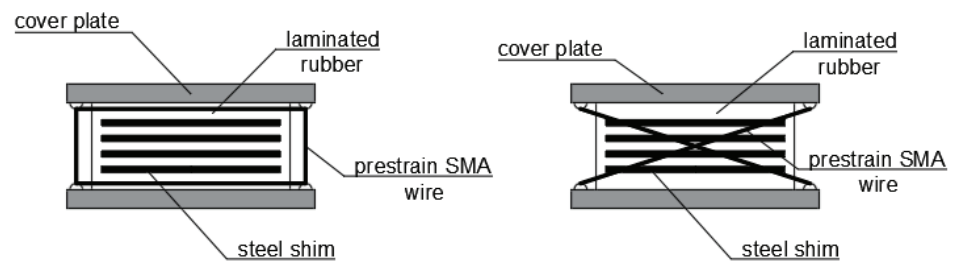

Fig. 2 Examples of SMA-rubber base isolators $[9,10]$.

The unique characteristics of SMA assure satisfactory performance in such application. First, superelasticity, which results in self-centering force, which brings the structure to the initial configuration when the seismic action is over. Secondly, the high stiffness for small displacements prevents from the movement of a structure caused by nonessential, from the point of base isolation, forces. Finally, the good energy dissipation of SMA results in reduction of accelerations and displacements during an earthquake [5]. The researches [8,10] proof that the performance of SMArubber base isolators is better in comparison to conventional devices. The main disadvantage is a price of the material and installation specially in existing buildings [2].

The application of SMA based devices is particularly promising for seismic retrofitting of architectural heritage. Properties of SMA results in reduction of a force transferred during moderate and strong earthquakes to the structure by embedded ties. Lower stiffness under higher horizontal actions, which appear during strong earthquakes, allows for "controlled displacements". This phenomenon permit the structure to dissipate part of the energy through microcracking instead of dangerous macrocracking [11]. The device that include a pre-tensioned SMA wires was developed in a frame of ISTECH project and later applied in several historical structures $[12,13]$. The SMA device could be used to prevent large deformations of slender structures, like in bell tower of San Giorgio church in Trignano [14]. Another possibility for improvement of historical masonry is out-of-plane collapse of facades. The examples of filed applications of SMA devices can be found in the Basilica of San Francisco in Assisi and the Cathedral of San Feliciano in Foligno [15]. In such case the ties with SMA devices are joining the facade with lateral walls usually by additional structure, for example, reinforced concrete rib. The schemes of the SMA devices arrangement in both kinds of application is given in the Fig. 3 . 
a)

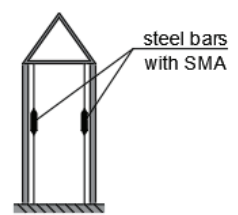

b)

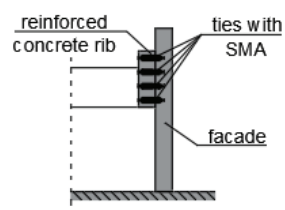

Fig. 3 Schemes of the SMA devises arrangement for retrofitting of (a) slender structures [14] and (b) out-ofplane collapse of facades [15].

SMA applications are not only related to the mitigation of seismic hazards results. The other one could be an improvement of fatigue resilience of stay cables of bridges, studied by Torra et al. [16] and Dieng et al. [17]. Structural cables due to the large flexibility, relatively small mass and low damping properties are particularly subjected to the vibrations. A passive damping devices with SMA could significantly reduce fatigue effects due to reduction of vibration amplitude and stress cycles in stay cables. The scheme of elements arrangement in such application is given in Fig. 4. The performance of other possible application of SMA devices for bridge engineering was studied by Zbiciak et al. [18].

a)

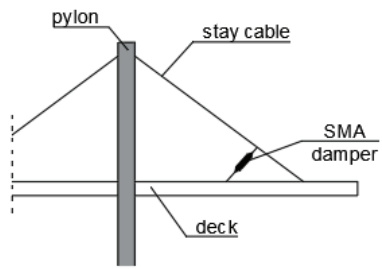

b)

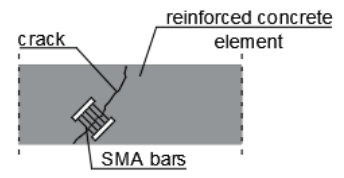

Fig. 4 Examples of SMA applications: (a) stay cable damper [16] and (b) external post-tensioning reinforcement [5].

The ability of recovering the initial shape (shape memory) of the SMA could be also used as external post-tensioning system of existing structures. A field example of rehabilitation of cracked reinforced concrete bridge in Michigan is given by Soroushian et al. [19]. The bridge suffered because of insufficient shear resistance which resulted in appearance of cracks. Due to the shape memory effect the post-tensioning could have been applied without any additional tensioning device. The preelongated SMA bars were anchored to the reinforced concreate girder (Fig. 4) and heated by electric 
current. The force generated by restoring the initial shape of SMA bars was transferred to the structure resulting in closing of the cracks.

\section{NEW CONSTITUTIVE MODEL OF SMA}

\subsection{THE INTERNAL LOOPS PHENOMENON}

The presence of internal loops, also called subloops, is a significant characteristic of some of the SMA (e.g. [20-22]). The schematic graph of such loop is given in the Fig. 5. In comparison to external loop $\mathrm{OA}_{1} \mathrm{M}_{1} \mathrm{M}_{2} \mathrm{~A}_{2} \mathrm{O}$, the exemplary internal loop is given $\mathrm{OA}_{1} \mathrm{BCDEFGHA} \mathrm{A}_{2} \mathrm{O}$. This kind of phenomenon is a result of the change of parent phase of SMA, at the point $A_{1}$, into martensite phase at the point $\mathrm{M}_{1}$. In case of not complete phase transformation, at the point $\mathrm{B}$, during the unloading (BCD), the reverse transformation occurs, starting at the point $\mathrm{C}$ etc.

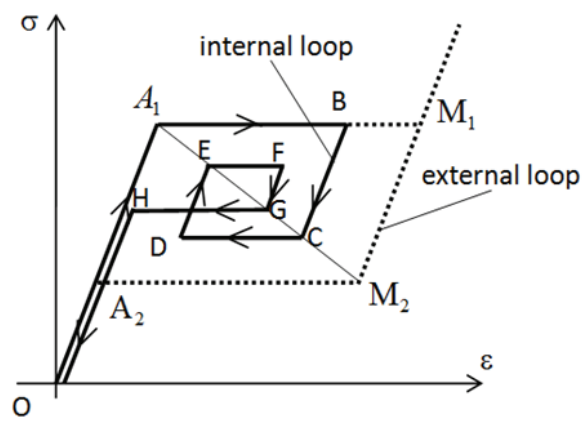

Fig. 5 The hysteresis loops of SMA at constant temperature.

The constitutive models, which take into consideration the phenomenon of internal loops formation, are presented in the literature [23]. The aim of this article is a proposal of new method of formulation of physical relations of SMA material based on special rheological structure, which includes modified Kepes's model [24]. This new rheological element, introduced as dual-phase plasticity body, will be presented in the context of martensite phase transformation. The characteristic feature of presented rheological elements is substitution of the classical rigid perfectly plastic element (Saint-Venant) with the mentioned dual-phase plastic element. We assume the non-linear effects to be presented only in 
deviatoric subspaces of stresses and strains. Presented methodology allows to formulate the constitutive relationships of SMA as a set of explicit differential equations.

\subsection{RHEOLOGICAL MATERIAL MODEL WITH DUAL-PHASE PLASTICITY}

At first, the hypothetical graph of the strain $\left(\varepsilon_{p}\right)$ versus time $(t)$ for the mentioned plastic body should be considered (Fig. 6). The graph could be divided into sections: $\left[0, t_{1}\right),\left[t_{1}, t_{2}\right),\left[t_{2}, t_{3}\right)$, and $\left[t_{3}, t_{4}\right)$, in which a function to be considered is characterized as non-decreasing or non-increasing. The function is non-decreasing in sections $\left[0, t_{1}\right),\left[t_{2}, t_{3}\right)$ and non-increasing in sections, $\left[t_{1}, t_{2}\right),\left[t_{3}, t_{4}\right)$.

After comparison of graphs in Fig. 5 and Fig. 6 the following conclusions could be formulated:

- while the strains increases the transformation of parent phase (austenite) into martensite occurs;

- while the strain decreases the reverse transformation occurs.

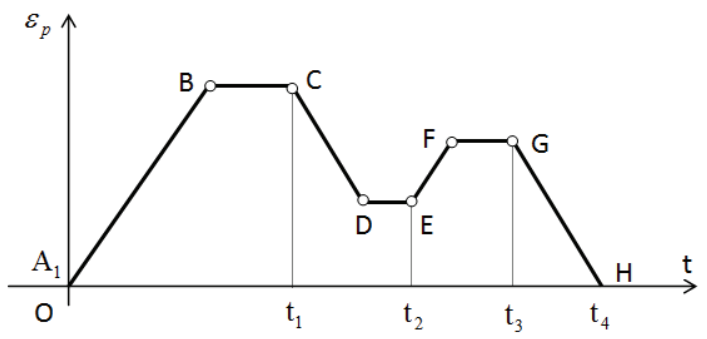

Fig. 6 The graph of strain versus time.

The volumetric fraction of martensite phase in the SMA will be defined by the factor $\xi \in[0,1]$, that:

- $\xi=0$, when only the parent phase is present;

- $\xi=1$, when only the martensite phase is present.

In the Fig. 5 , the fraction of martensite phase are determined by points $A_{1} M_{2}$, what means that at the point $A_{1}, \xi=0$ and at the point $M_{2}, \xi=1$. The value of the factor at the point $B$ is determined by the ratio of the length of sections

$$
\xi_{\mathrm{B}}=\frac{A_{1} C}{A_{1} M_{2}}
$$


and the change during the unloading from point $C$ to $D$ is equal

$$
\xi_{C D}=\frac{C E}{A_{1} M_{2}}
$$

The dual-phase plastic body can be interpreted as a modification of the Kepes rheological element described by Grzesikiewicz and Zbiciak [24]. The characteristic feature of this new model is a possibility of discontinues variations of the yield strength $\left(k_{p}\right)$ with values from the range of $\left[0, k_{m}\right]$, where $k_{m}$ is value of yield strength of the martensite phase $(\xi=1)$. In Fig. 5, the value of $k_{m}$ is specified by the section $M_{1} M_{2}$.

The base for the determination of the yield strength value is a function which describes the evolution of the strain norm of the dual-phase plastic body $\left\|\varepsilon_{p}\right\|$ and the following rules:

- The graph of the function that defines the norm of the strain could be divided into sections of time, in which the strain norm is not decreasing or not increasing, as it is shown in the Fig. 7;

- in each specified time section the yield strength changes from the value of 0 to the value which is proportional to the change of strain norm in the same time section.

a)

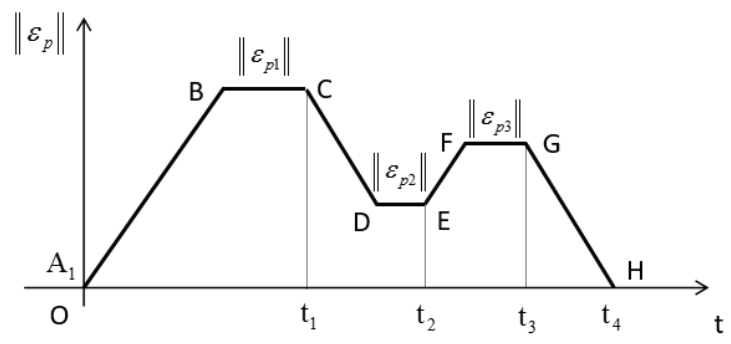

b)

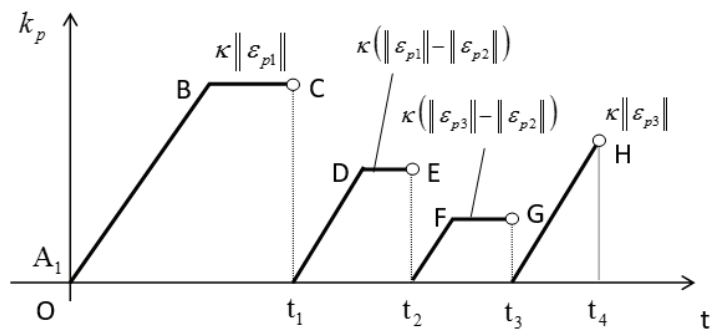

Fig. 7 The graphs of the strain norm $\left\|\varepsilon_{\mathrm{p}}\right\|$ (a) and yield strength $\mathrm{k}_{\mathrm{p}}(\mathrm{b})$

$(\kappa-$ proportionality ratio). 
Fig. 7 schematically visualizes the function that describes the variation of strain norm $\left\|\varepsilon_{p}\right\|$ as well as the function defining the yield strength $k_{p}$.

Fig. 8 represents the hysteretic loop for a double-phase plastic body, that was obtained as a result of a strain process, which is shown in Fig. 7a. This loop represents relationship between stress $(\sigma)$ and strain $\left(\varepsilon_{p}\right)$, established based on Fig. 7.

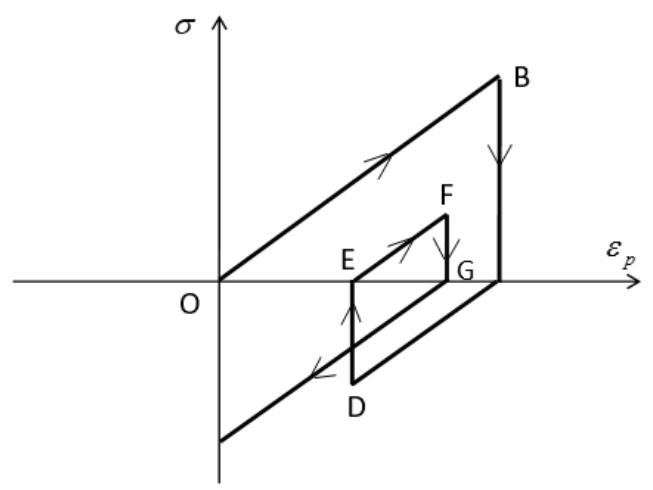

Fig. 8 Hysteretic loop for dual-phase plasticity body established based on Fig. 7.

Let us analyse the mathematical description of the double-phase plastic model starting from a special definition of a mapping (transform), which associates a non-continuous function possessing finite number of discontinuities with the continuous real function of one variable.

Let us consider continuous function belonging to the set _

$$
\mathrm{F}:=\left\{f \in C^{1}\left(R^{+}, R\right): f(0)=0, \dot{f}(0) \neq 0\right\}
$$

For the function $f \in \sigma^{-}$we define the following increasing series $\left\{t_{n}\right\}_{n=0}^{\infty}$, such as

$$
\begin{aligned}
& t_{0}:=0, \\
& t_{k+1}:=\inf \left\{t>t_{k}: \quad \operatorname{sign} \dot{f}\left(t_{k}+0\right) \cdot \operatorname{sign} \dot{f}(t)=-1\right\}, \quad k=0,1,2, \ldots
\end{aligned}
$$

where $\dot{f}\left(t_{k}+0\right)$ denotes a right derivative of function $f$. 
The map T mapping function $f \in \circledast$ to the set of non-continuous functions, is defined as

$$
\mathrm{T}(f)(t):=\sum_{k=0}^{\infty}\left[f(t)-f\left(t_{k}\right)\right] \chi_{\left[t_{k}, t_{k+1}\right)}(t)
$$

where the function $\chi$ is an indicator function of the set

$$
\chi_{[a, b)}(t)= \begin{cases}1, & \text { if } t \in[a, b), \\ 0, & \text { if } t \notin[a, b) .\end{cases}
$$

The schematic illustration of the effect of the $T$ map is given in the Fig. 9.

a)

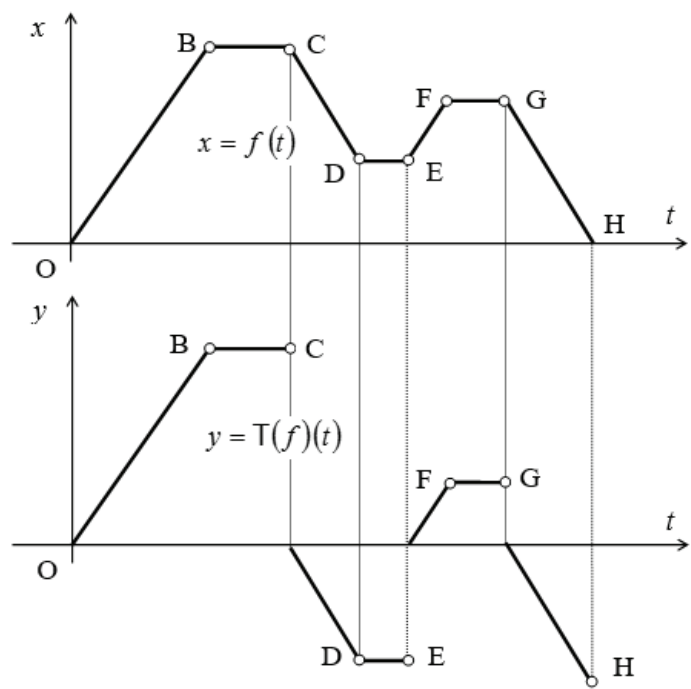

Fig. 9 Graphs of the function $f$ and the set $\mathrm{T}(f)$.

The mathematical description of one-dimensional relations of the dual-phase plastic body is defined by following relations:

$$
\dot{\varepsilon}_{p}=\lambda \sigma, \quad \lambda \geq 0, \quad \frac{1}{2} \sigma^{2} \leq k_{p}^{2}\left(\left|\varepsilon_{p}\right|\right), \quad \lambda\left(\frac{1}{2} \sigma^{2}-k_{p}^{2}\left(\left|\varepsilon_{p}\right|\right)\right)=0
$$


where

$$
k_{p}\left(\left|\varepsilon_{p}(t)\right|\right)=\kappa\left|\mathrm{T}\left(\left|\varepsilon_{p}\right|\right)(t)\right|
$$

if $\kappa$ is a coefficient determining plastic characteristic of the body.

Fig. 10 represents graphical symbol of dual-phase plastic body together with $\sigma$ and $\varepsilon_{p}$ variables.

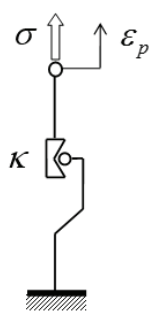

Fig. 10 Graphical symbol of dual-phase plastic body.

\subsection{MATHEMATICAL DESCRIPTION OF SMA WITH INTERNAL LOOPS}

The previously described model of dual-phase plastic body will be used for the formulation of rheological model that represents behaviour of SMAs including the internal hysteresis loops. Let us consider a structure given in Fig. 11. The model represents deviatoric subspace of strains and stresses. The model is composed of three elements. The upper spring symbolises elastic properties of the SMA described by the Hooke's law. Double-phase plastic element is correlated with deviatoric stresses $\mathrm{s}$ pl. The last element possessing the state of stresses spe represents, so called, pseudo-elastic body [24]. 


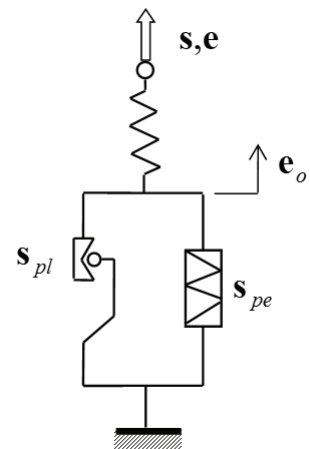

Fig. 11 Scheme of SMA with internal loops.

The complete set of constitutive equations defining the SMA with internal loops is as follows

$$
\begin{aligned}
& \mathbf{s}_{p e}+\mathbf{s}_{p l}=2 G\left(\mathbf{e}-\mathbf{e}_{o}\right), \\
& \mathbf{e}_{o}=\lambda_{p e} \mathbf{s}_{p e} ; \quad \lambda_{p e} \geq 0 ; \quad \frac{1}{2}\left\|\mathbf{s}_{p e}\right\|^{2} \leq k_{p e}^{2} ; \quad \lambda_{p e}\left(\frac{1}{2}\left\|\mathbf{s}_{p e}\right\|^{2}-k_{p e}^{2}\right)=0, \\
& \dot{\mathbf{e}}_{o}=\lambda_{p l} \mathbf{s}_{p l} ; \quad \lambda_{p l} \geq 0 ; \quad \frac{1}{2}\left\|\mathbf{s}_{p l}\right\|^{2} \leq k_{p l}^{2}\left(\left\|\mathbf{e}_{o}\right\|\right), \quad \lambda_{p l}\left(\frac{1}{2}\left\|\mathbf{s}_{p l}\right\|^{2}-k_{p l}^{2}\left(\left\|\mathbf{e}_{o}\right\|\right)\right)=0,
\end{aligned}
$$

where

$$
k_{p l}\left(\left\|\mathbf{e}_{o}(t)\right\|\right)=\kappa\left|\mathrm{T}\left(\left\|\mathbf{e}_{o}\right\|\right)(t)\right|
$$

Eq. (0.1) represents the equilibrium of rheological model visualised in Fig. 11 taking into account the decomposition of the stresses and the Hooke's law in the elastic branch. Sets of e (0.2) and (0.3) are very similar. The only deference is that the quantities defining non-elastic strains $\mathbf{e}_{0}$ are defined in algebraic form (see Eq. (0.2)) or in differential form (Eq. (0.3)). The interpretation of Eq. (0.3) using the notion of theory of plasticity leads to associated flow rule completed by Kuhn-Tucker conditions [25].

The given equations frames the base for determination of a form of the function $f_{S M A}$, which relations could be derived to: 


$$
\begin{aligned}
& \mathbf{s}=2 G\left(\mathbf{e}-\mathbf{e}_{\mathbf{0}}\right), \\
& \dot{\mathbf{e}}_{\mathbf{0}}=f_{S M A}\left(e_{o}, e, \dot{e}\right) .
\end{aligned}
$$

Fig. 12 represents a schematic graph of the hysteretic loop of the rheological structure from Fig. 11.

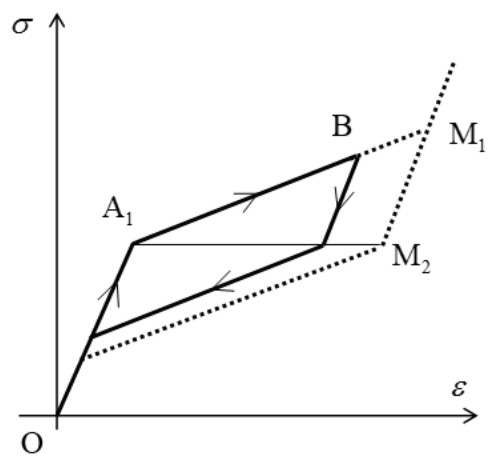

Fig. 12 Hysteretic loop of the rheological structure from Fig. 11.

Let us focus on the description of the $f_{S M A}$ function. The variation of the yield strength based on the Eq. (0.4) results in a sort of similarities to the plastic material with an isotropic strengthening. Absolute value of the map, which appears in the Eq. (0.4), could be computed by introducing a new variable $\mathbf{z}$, which satisfy the relation

$$
\|\mathbf{z}(t)\|=\left|\mathbf{T}\left(\left\|\mathbf{e}_{o}\right\|\right)(t)\right|
$$

Value of the tensor $\mathbf{z}$ is computed for each moment $t$ based on the following relation

$$
\mathbf{z}(t)=\mathbf{e}_{\mathrm{o}}(t)-\mathbf{e}_{\mathrm{o}}(\tilde{t})
$$

where $\tilde{t}$ denotes a time instant of the change of $m$ coefficient, given as an equation

$$
m(t):=\left\{\begin{array}{cl}
1 & \text { if }\|\mathbf{s}(t)\| \geq \sqrt{2} k_{p e} \\
-1 & \text { if }\|\mathbf{s}(t)\|<\sqrt{2} k_{p e}
\end{array}\right.
$$


For the function $m$ we define the increasing sequence $\left\{t_{n}\right\}_{n=0}^{\infty}$ that

$$
\begin{aligned}
& t_{0}:=0 \\
& t_{k+1}:=\left\{t>t_{k}: \quad m\left(t_{k+1}\right) \cdot m\left(t_{k}\right)=-1\right\}, \quad k=0,1,2, \ldots
\end{aligned}
$$

Formulated sequence allows to determine the value $\tilde{t}$, for each time instant $t$, based on the relation

$$
\widetilde{t}=\inf \left\{t_{n}\right\}_{n=0}^{\infty}
$$

Final form of the function $f_{S M A}$ is given without establishing formal proofs:

$$
f_{S M A}\left(\mathbf{e}_{\mathrm{o}}, \mathbf{e}, \dot{\mathbf{e}}\right)= \begin{cases}\mathbf{0} & \text { if }\left\|\mathbf{e}_{\mathrm{o}}\right\|=0 \text { and } 2 G\|\mathbf{e}\|<\sqrt{2} k_{p e}, \\ \mathbf{0} & \text { if }\left\|\mathbf{e}_{\mathrm{o}}\right\| \neq 0 \text { and }\left\|\mathbf{s}_{p l}\right\|<\sqrt{2} \kappa\|\mathbf{z}\|, \\ \frac{2 G \dot{\mathbf{e}} \cdot \mathbf{e}}{(2 G+\kappa)\|\mathbf{e}\|^{2}} & \text { if }\left\|\mathbf{e}_{\mathrm{o}}\right\|=0 \text { and } 2 G\|\mathbf{e}\|=\sqrt{2} k_{p e}, \\ \lambda_{p l} \mathbf{s}_{p l} & \text { if }\left\|\mathbf{e}_{\mathrm{o}}\right\| \neq 0 \text { and }\left\|\mathbf{s}_{p l}\right\|=\sqrt{2} \kappa\|\mathbf{z}\|,\end{cases}
$$

where

$$
\begin{aligned}
& \lambda_{p l}=\frac{G\left[\mathbf{s}_{p l} \cdot \dot{\mathbf{e}}\right]^{+}}{\kappa^{2}}\left\{\mathbf{e}_{\mathrm{o}} \cdot \mathbf{s}_{p l}+\|\mathbf{z}\|^{2}\left[2 G+\frac{\sqrt{2} k_{p e}}{\left\|\mathbf{e}_{\mathrm{o}}\right\|}\left(1-\left(\frac{\mathbf{s}_{p e} \cdot \mathbf{s}_{p l}}{2 \kappa k_{p e}\|\mathbf{z}\|}\right)^{2}\right)\right]\right\}^{-1}, \\
& \mathbf{s}_{p l}=2 G\left(\mathbf{e}-\mathbf{e}_{\mathrm{o}}\right)-\frac{\sqrt{2} k_{p e}}{\left\|\mathbf{e}_{\mathrm{o}}\right\|} \mathbf{e}_{\mathrm{o}}, \\
& \mathbf{s}_{p e}=\frac{\sqrt{2} k_{p e}}{\left\|\mathbf{e}_{\mathrm{o}}\right\|} \mathbf{e}_{\mathrm{o}} .
\end{aligned}
$$

The SMA constitutive model, presented in this article, demonstrate a strengthening after reaching the limit stresses of the parent phase (segment $A_{1} M_{1}$ in Fig. 12). As a consequence the segment $A_{1} M_{2}$, which determines a beginning of the reverse transformation (martensite to austenite) is horizontal. In order to obtain the effect as shown in Fig. 5 the rheological scheme has to be modified by the introduction of a spring with a negative stiffness, marked with an arrow in Fig. 13. If the absolute 
value of the spring stiffness will be equal to the stiffness of the dual-phase plastic body (Fig. 13, $\beta=1$ ), the segment $A_{l} M_{l}$ will be horizontal.

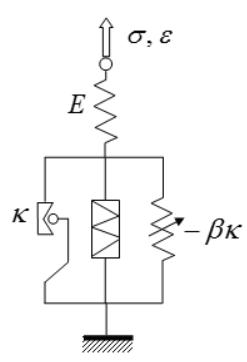

$$
\begin{aligned}
& \alpha_{1}=\operatorname{arctg} E \\
& \alpha_{2}=\operatorname{arctg} \frac{E(1-\beta) \kappa}{E+(1-\beta) \kappa} \\
& \beta \in\langle 0,1\rangle
\end{aligned}
$$

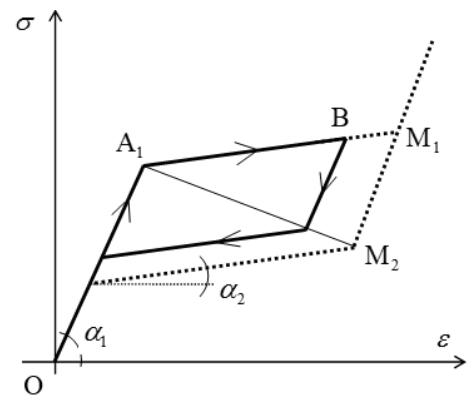

Fig. 13 Rheological scheme of SMA with a spring with negative stiffness and its hysteretic loop with material parameter given.

\section{NUMERICAL IMPLEMENTATION}

In order to perform numerical simulation of SMA models, the mechanical characteristics of elements of the rheological model had to be identified. There were obtained based on the results of experiments presented in the literature (e.g.[20,22,26]). The phenomenon of internal loops exposed in the experiments of Savi and Pavia [20] or Peultier et al. [22] depends strictly on the loading procedure therefore it cannot be considered as a constitutive characteristic. However, the external loop is a constant feature that derives directly from the mechanical characteristic of SMA and it is independent of load course. The idealization of experimental results and identification of main mechanical characteristic is given in Fig. 14. Analysis of the idealized graph allows to identify the mechanical parameters of elements of the rheological model. 


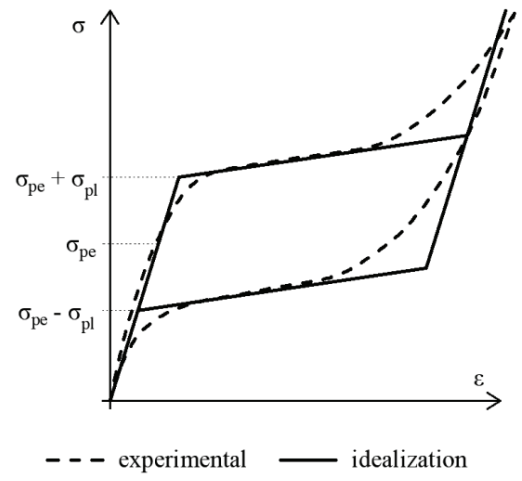

Fig. 14 Idealization of external loop of SMA.

Behaviour of the material was tested on a three dimensional finite element in ABAQUS/Explicit software. ABAQUS does not possess any build-in SMA constitutive model. Thus, implementation of our SMA model with internal loops should be performed by UMAT or VUMAT subroutine written in Fortran. UMAT subroutine is used in ABAQUS/Standard routine while VUMAT is dedicated for ABAQUS/Explicit module.

Based on the code within VUMAT subroutine a simulation was performed on a single 8-node element C3D8 [27] under the pure shear load. The kinematic excitation was applied to the nodes at the top of the element, in the $\mathrm{x}$-axis direction in accordance to time course give in Fig. 15.
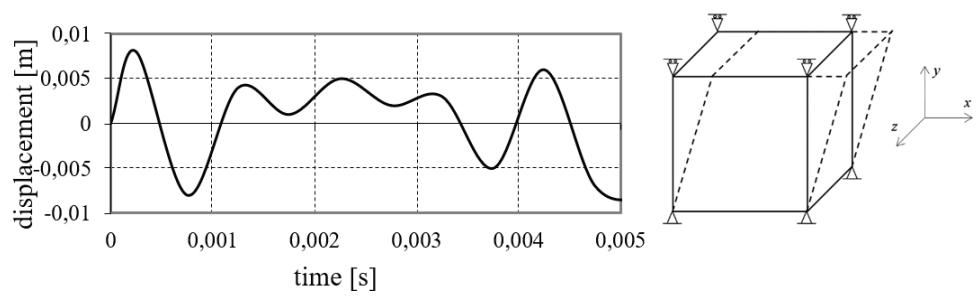

Fig. 15 Time course of the kinematic excitation applied to the finite element in the $\mathrm{x}$-axis direction.

The mechanical parameters of rheological model used for the simulation are given in the Table 1 . Test were performed for two values of $\beta=1$ and $\beta=0$. Results are given as a hysteresis loops (shear components of stress's and strain's states) in Fig. 16 and Fig. 17.

Table 1. Mechanical properties of SMA with internal loops rheological model. 


\begin{tabular}{ccccccc}
\hline$\rho\left[\mathrm{kg} / \mathrm{m}^{3}\right]$ & $E[\mathrm{GPa}]$ & $K[\mathrm{GPa}]$ & $G[\mathrm{GPa}]$ & $\kappa[\mathrm{GPa}]$ & $k_{p e}[\mathrm{MPa}]$ & $\Delta[1]$ \\
\hline 6500 & 50,00 & 41,67 & 19,23 & 9,62 & 400 & 0,04 \\
\hline
\end{tabular}

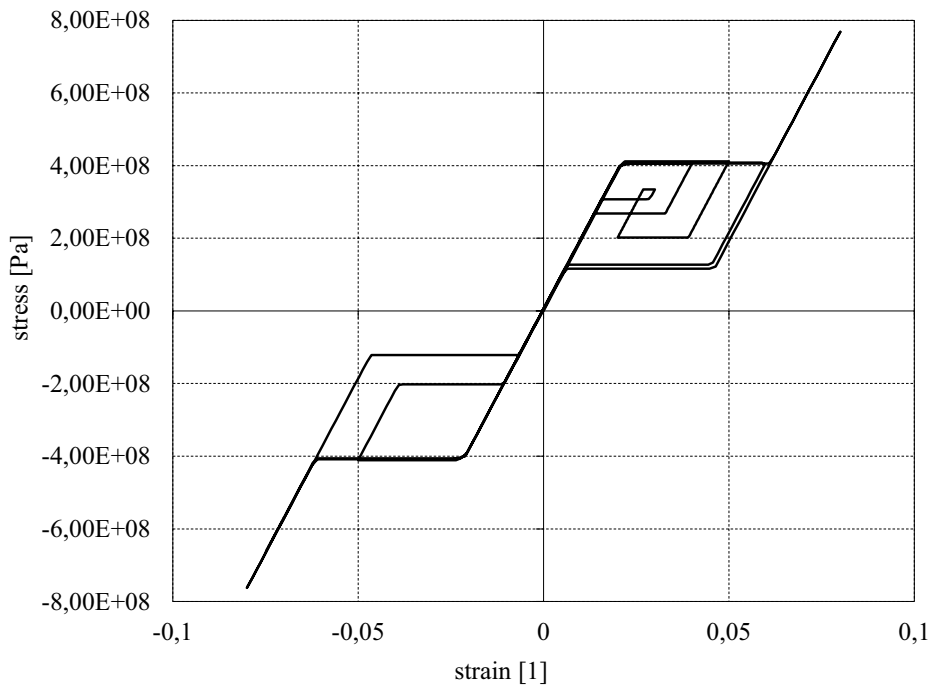

Fig. 16 Hysteresis loop for $\beta=1$.

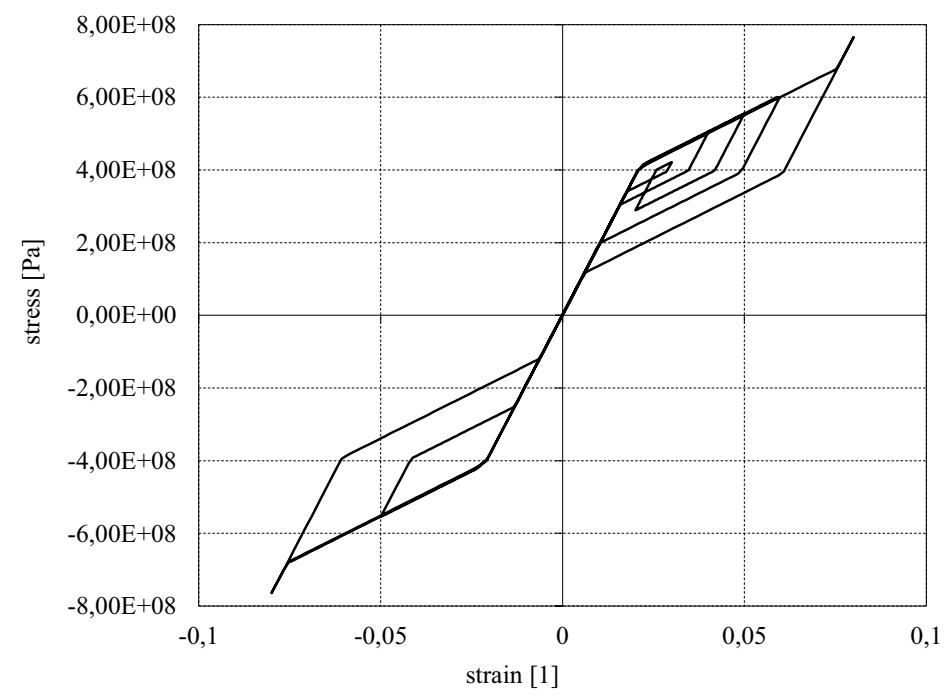


Fig. 17 Hysteresis loop for $\beta=0$.

\section{CONCLUSION}

The presented model is a continuation of rheological schemes approach to SMA modelling of Grzesikiewicz and Zbiciak [24,28-30]. The great advantage of this approach is the form of constitutive relationships as a set of explicit differential equations, which could be directly programmed within commercial FEM codes. As an example we demonstrated the results of implementation of constitutive equations of our model in ABAQUS. The results shown in the previous chapter demonstrate validity of Eq. (0.5) along Eq. (0.6) and Eq. (0.7).

The further works on the model will be devoted to the structural analysis of possible applications, especially analysis of influence of internal loops on the damping effect of SMA.

One of the main aspects of further SMA applications is development of robust computational models of SMA behaviours [1]. Authors believe that the presented model has a potential to contribute in the future SMA development.

\section{REFERENCES}

J. Mohd Jani, M. Leary, A. Subic, M.A. Gibson, A review of shape memory alloy research, applications and opportunities, Materials and Design. 56 (2014) 1078-1113.

Y. Chang, Wenn-Shao; Araki, Use of shape-memory alloys in construction : a critical review, Proceedings of the Institution of Civil Engineers - Civil Engineering. 169 (2016) 87-95.

W. Terlikowski, Interdisciplinary diagnostics in the process of revitalization of historic buildings, in terms of changing their function, MATEC Web of Conferences. 117 (2017) 00165.

K. Wasilewski, A. Zbiciak, Proposal of a new constitutive model for SMA with internal loops, in: F.M. Mazzolani (Ed.), 3rd International Conference on Protection of Historical Constructions, Lisbon, 2017: pp. 129-130.

C. Menna, F. Auricchio, D. Asprone, Applications of Shape Memory Alloys in Structural Engineering, Elsevier Ltd, 2015.

F. Auricchio, D. Fugazza*, R. Desroches, Earthquake Performance of Steel Frames With Nitinol Braces, Journal of Earthquake Engineering. 10 (2006) 45-66.

H. Tamai, Y. Kitagawa, Pseudoelastic behavior of shape memory alloy wire and its application to seismic resistance member for building, Computational Materials Science. 25 (2002) 218-227.

K. Wilde, P. Gardoni, Y. Fujino, Base isolation system with shape memory alloy device for elevated highway bridges, Engineering Structures. 22 (2000).

E. Choi, T.H. Nam, J.T. Oh, B.S. Cho, An isolation bearing for highway bridges using shape memory alloys, Materials Science and Engineering A. 438-440 (2006) 1081-1084.

S. Das, S.K. Mishra, Optimal performance of buildings isolated by Shape-Memory-Alloy-Rubber- Bearing (SMARB) under random earthquakes, International Journal of Computational Methods in Engineering Science and Mechanics. 15 (2014) 265-276.

1 M.G. Castellano, M. Indirli, A. Martelli, Progress of application, research and development, and design guidelines for shape memory alloy devices for cultural heritage structures in Italy, in: Smart Structures and 
Materials 2001: Smart Systems for Bridges, Structures, and Highways, 2001: pp. 250-261.

\section{Indirli, M.G. Castellano, Shape Memory Alloy Devices for the Structural Improvement of Masonry Heritage} Structures, International Journal of Architectural Heritage. 2 (2008) 93-119.

F.M. Mazzolani, A. Mandara, Modern trends in the use of special metals for the improvement of historical and monumental structures, Engineering Structures. 24 (2002) 843-856.

M. Indirli, M.G. Castellano, P. Clemente, A. Martelli, Demo-application of shape memory alloy devices: The rehabilitation of the S. Giorgio Church Bell-Tower, Proceedings of SPIE - The International Society for Optical Engineering. 4330 (2001) 262-272.

M.G. Castellano, Seismic protection of monuments by shape memory alloy devices and shock transmitters, (2005) 1229-1234.

V. Torra, C. Auguet, A. Isalgue, G. Carreras, P. Terriault, F.C. Lovey, Built in dampers for stayed cables in bridges via SMA. The SMARTeR-ESF project: A mesoscopic and macroscopic experimental analysis with numerical simulations, Engineering Structures. 49 (2013) 43-57.

L. Dieng, G. Helbert, S.A. Chirani, T. Lecompte, P. Pilvin, Use of shape memory alloys damper device to mitigate vibration amplitudes of bridge cables, Engineering Structures. 56 (2013) 1547-1556.

A. Zbiciak, R. Michalczyk, R. Oleszek, Vibration reduction of cable-stayed bridge model retrofitted with SMA restrainers, Vibroengineering PROCEDIA. 3 (2014) 180-185.

P. Soroushian, K. Ostowari, A. Nossoni, H. Chowdhury, Repair and Strengthening of Concrete Structures Through Application of Corrective Posttensioning Forces with Shape Memory Alloys, Transportation Research Record: Journal of the Transportation Research Board. 1770 (2001) 20-26.

M.A. Savi, A. Paiva, Describing internal subloops due to incomplete phase transformations in shape memory alloys, Archive of Applied Mechanics. 74 (2005) 637-647.

1 A. Ziółkowski, Pseudosprężystość stopów z pamięcią kształtu badania doświadczalne i opis teoretyczny, Prace Instytutu Podstawowych Problemów Techniki PAN. 6 (2006) 200.

B. Peultier, T. Ben Zineb, E. Patoor, Macroscopic constitutive law of shape memory alloy thermomechanical behaviour. Application to structure computation by FEM, Mechanics of Materials. 38 (2006) 510-524.

A. Masud, K. Xia, A variational multiscale method for inelasticity: Application to superelasticity in shape memory alloys, Computer Methods in Applied Mechanics and Engineering. 195 (2006) 4512-4531.

4 W. Grzesikiewicz, A. Zbiciak, Constitutive modelling of pseudoelastic material using Kepes-type rheological element, Computer Systems Aided Science and Engineering Work in Transport, Mechanics and Electrical Engineering. 122 (2008) 159-164.

N.S. Ottosen, M. Ristinmaa, The mechanics of constitutive modeling, Elsevier, 2005.

F. Auricchio, E. Sacco, A one-dimensional model for superelastic shape-memory alloys with different elastic properties between austenite and martensite, International Journal of Non-Linear Mechanics. 32 (1997) 11011114. ABAQUS Analysis User's Manual, Ver. 6.12, Dassault Systèmes, 2012.

W. Grzesikiewicz, A. Wakulicz, A. Zbiciak, Mathematical modelling of rate-independent pseudoelastic SMA material, International Journal of Non-Linear Mechanics. 46 (2011) 870-876.

9 W. Grzesikiewicz, A. Zbiciak, Mathematical modelling of rate-dependent SMA material subjected to dynamic loads, in: Proceedings of 15th French-Polish Seminar of Mechanics, Polytech'Lille, Villeneuve d'Ascq, France, 2007: pp. 138-143.

A. Zbiciak, Dynamic analysis of pseudoelastic SMA beam, International Journal of Mechanical Sciences. 52 (2010) 56-64. 


\section{LIST OF FIGURES AND TABLES:}

Fig. 1 Schematic representation of possible applications of SMA for frame bracing [5-7].

Rys. 1 Schematy zastosowania SMA jako ściągi w ramach [5-7].

Fig. 2 Examples of SMA-rubber base isolators $[9,10]$.

Rys. 2 Przykłady izolatorów sejsmicznych z wykorzystaniem gumy i SMA $[9,10]$.

Fig. 3 Schemes of the SMA devises arrangement for retrofitting of (a) slender structures [14] and (b) out-ofplane collapse of facades [15].

Rys. 3 Schematy zastosowania urządzeń zawierających SMA do (a) wzmacniania smukłych konstrukcji [14] oraz (b) zabezpieczenia fasady przed przewróceniem się fasady w kierunku prostopadłym do jej płaszczyzny [15].

Fig. 4 Examples of SMA applications: (a) stay cable damper [16] and (b) external post-tensioning reinforcement [5].

Rys. 4 Przykłady zastosowania SMA jako: (a) thumika cięgien w moście podwieszonym [16] oraz (b) zewnętrznego sprężenia [5].

Fig. 5 The hysteresis loops of SMA at constant temperature.

Rys. 5 Pętle histerezy stopu SMA w stałej temperaturze.

Fig. 6 The graph of strain versus time.

Rys. 6 Wykres odkształcenia w czasie.

Fig. 7 The graphs of the strain norm $\left\|\varepsilon_{p}\right\|$ (a) and yield strength $k_{p}$ (b) ( $\kappa$ - proportionality ratio).

Rys. 7 Przebiegi normy odkształcenia $\left\|\varepsilon_{\mathrm{p}}\right\|$ (a) oraz granicy plastyczności $\mathrm{k}_{\mathrm{p}}(\mathrm{b})$

( $\kappa$ - współczynnik proporcjonalności).

Fig. 8 Hysteretic loop for dual-phase plasticity body established based on Fig. 7.

Rys. 8 Pętla histerezy ciała z dwufazową plastycznością, ustalona na podstawie Rys. 7.

Fig. 9 Graphs of the function $f$ and the set $\mathrm{T}(f)$.

Rys. 9 Wykresy funkcji $f$ oraz transformaty $\mathrm{T}(f)$.

Fig. 10 Graphical symbol of dual-phase plastic body.

Rys. 10 Symbol graficzny dwufazowego ciała plastycznego.

Fig. 11 Scheme of SMA with internal loops.

Rys. 11 Schemat materiału SMA z pętlami wewnętrznymi

Fig. 12 Hysteretic loop of the rheological structure from Fig. 11.

Rys. 12 Pętla histerezy struktury pokazanej na Rys. 11.

Fig. 13 Rheological scheme of SMA with a spring with negative stiffness and its hysteretic loop with material parameter given. 
Rys. 13 Schemat reologiczny SMA ze sprężyną o ujemnej sztywności oraz jego pętla histerezy z opisanymi parametrami materiałowymi.

Fig. 14 Idealization of external loop of SMA.

Rys. 14 Wyidealizowany wykres pętli zewnętrznej materiału SMA.

Fig. 15 Time course of the kinematic excitation applied to the finite element in the $\mathrm{x}$-axis direction.

Rys. 15 Przebieg czasowy przemieszczenia w kierunku osi x, przyłożonego do górnych węzłów elementu (wymuszenie kinematyczne).

Fig. 16 Hysteresis loop for $\beta=1$.

Rys. 16 Pętla histerezy przy $\beta=1$.

Fig. 17 Hysteresis loop for $\beta=0$.

Rys. 17 Pętla histerezy przy $\beta=0$.

Tab. 1. Mechanical properties of SMA with internal loops rheological model.

Tab. 1 Właściwości mechaniczne elementów modelu reologicznego SMA z pętlami wewnętrznymi 


\section{MODELOWANIE KONSTYTUTYWNE I IMPLEMENTACJA NUMERYCZNA MATERIALU SMA Z PĘTLAMI WEWNĘTRZNYMI}

Słowa kluczowe: stopy z pamięcią kształtu (SMA); model reologiczny; symulacja dynamiczna.

\section{STRESZCZENIE:}

Artykuł przedstawia model konstytutywny stopów z pamięcią kształtu (ang. Shape Memory Alloy - SMA) wraz z wynikami przeprowadzonej analizy dynamicznej. Zastosowanie urządzeń wykorzystujących SMA w dziedzinie inżynierii lądowej skupia się głównie na ograniczeniu skutków odziaływań sejsmicznych w nowo powstających oraz istniejących budynkach, w tym w obiektach historycznych. Odrębnym zagadnieniem, w którym także wykorzystywane są urządzenia z SMA, jest poprawienie trwałości zmęczeniowej elementów konstrukcyjnych. W artykule przedstawiono wybrane możliwości zastosowania urządzeń z SMA w budownictwie. Wykorzystanie SMA do powyższych celów jest możliwe dzięki ich wyjątkowym właściwościom - efektowi pamięci kształtu oraz pseudosprężystości.

Prezentowany model konstytutywny uwzględnia także dodatkową właściwość SMA jaką są wewnętrzne pętle histerezy. W artykule przedstawiono metodę formułowania zależności fizycznych SMA na specjalnych strukturach reologicznych wykorzystujących zmodyfikowany model Kepesa (tzw. ciało z dwufazową plastycznością). Definicję tego elementu reologicznego przedstawiono na tle makroskopowego opisu przemian fazowych zachodzących w SMA. Jedną z zalet prezentowanego w artykule podejścia do formułowania zależności fizycznych jest uzyskanie zależności konstytutywnych w postaci jawnych równań różniczkowych. Zastosowanie prezentowanego modelu zostało przedstawione na przykładzie analizy dynamicznej trójwymiarowego elementu skończonego poddanego dynamicznemu wymuszeniu. 